Martin HEINRICH, Nicole KRONBERGER, Jürgen MAASZ ${ }^{1}$ \& Walter ÖTSCH (Linz)

\title{
Bildung für die Qualität der Lehre - Ein hoch- schuldidaktischer Lehrgang an der JKU Linz
}

\begin{abstract}
Zusammenfassung
Im Jahre 2004 startet an der Johannes Kepler Universität (JKU) Linz ein neues hochschuldidaktisches Bildungsangebot für alle Lehrenden, an dem alle nach dem 1.1.2004 Angestellten laut Dienstvertrag teilnehmen müssen. Der in diesem Beitrag vorgestellte Lehrgang „Bildung für die Qualität der Lehre“ wird vom Zentrum für soziale und interkulturelle Kompetenz der JKU angeboten. Das Konzept für den Lehrgang wurde in den letzten Monaten von einer interdisziplinären Arbeitsgruppe erstellt.

Im Beitrag skizzieren wir zunächst die Rahmenbedingungen und die Ausgangspunkte des Konzeptes. Im Zentrum steht die Vorstellung des geplanten Lehrgangs, der im Juni 2004 begonnen hat. Im Ausblick versprechen wir unter anderem einen Bericht über die Evaluation des ersten Lehrgangs.
\end{abstract}

\section{Schlüsselwörter}

Personalentwicklung, Qualität der Lehre

\section{Formation for the Quality of Education - A Curriculum for Didactics in Higher Education at JKU Linz}

\begin{abstract}
Since 2004 Johannes Kepler University (JKU) Linz offers a new curriculum for didactics in higher education that is obligatory to all those university lecturers appointed by the university after January 2004. This curriculum „Bildung für die Qualität der Lehre" (Formation for the Quality of Education) is organized by the university's Centre for Social and Intercultural Competence. The concept for the curriculum has been drawn up by an interdisciplinary working group within the last few months. In this contribution we outline the framework and the core ideas of the concept. The main part of the chapter details the projected curriculum that has started in June 2004. In a final outlook we promise an evaluative report on the first curriculum.
\end{abstract}

\section{Keywords}

Staff development, quality of teaching

${ }^{1}$ e-Mail: Juergen.Maasz@jku.at 


\section{Literaturverzeichnis}

Altrichter, Herbert, Brunner-Kranzmayr, Elisabeth, Dietz, Jeanette, Holley, Heinz, Kette, Gerhard, Ötsch, Walter, Pfeil, Gisela, Reber, Gerhard \& Stöbich, Tina: das Interdisziplinäre Zentrum für Soziale Kompetenz der Universität Linz Konzepte und erste Erfahrungen, in ZSfHD 2-3/2000, 101 - 109

Eckstein, Brigitte: Einmaleins der Hochschullehre. Praktische Einführung in die Grundlagen und Methoden. München 1978

Thonhauser, Josef: Portfolios in der Lehrer/innenbildung: Begriff, Erwartungen und Erfahrungen. In: Journal für LehrerInnenbildung, 1 (2001) Heft 4, 53-55

Thonhauser, Josef: Bewusstsein der eigenen Fähigkeit statt Rückblick auf übersprungene Hürden - die Portfolio-Idee in der Lehrerbildung. In: Winter, F., von der Groeben, A. \& Lenzen, K.-D. (Hg.): Leistung sehen, fördern, werten. Neue Wege für die Schule. Bad Heilbrunn /Obb. 2002, 184-191

Vierlinger, Rupert: Leistung spricht für sich selbst: „direkte Leistungsvorlage“ (Portfolio) statt Ziffernzensuren und Notenfetischismus. Heinsberg 1999

Im Internet (Stand 4/2004)

http://www.izhd.uni-hamburg.de/pdfs/Abschlussbericht.pdf

http://www.diejungeakademie.de/wisspol/angebote/Nordrhein-Westfalen.htm

http://www.prolehre.tu-muenchen.de/semprogr.htm

http://www.uni-bielefeld.de/lZHD/1024x768/index.htm 